\title{
Totem: Soa and Its Role in the Indigenous Peoples Lives of Negeri Hutumuri - Maluku
}

\section{Jenny Koce Matitaputty}

Department of History Education, Faculty of Teacher Training and Education, Universitas Pattimura, 97233, Ambon, Maluku Province, Indonesia

Corresponding Author: jenny.matitaputty@fkip.unpatti.ac.id

\section{ARTICLE INFO}

\section{Publication Info:}

Research Article

How to cite:

Matitaputty, J. K. (2021). Totem:

Soa and Its Role in the Indigenous

Peoples Lives of Negeri Hutumuri

- Maluku. Society, 9(2), 429-446.

DOI: $10.33019 /$ society.v9i2.358

Copyright (C) 2021. Owned by Author(s), published by Society

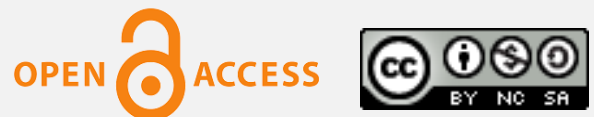

This is an open-access article.

\section{License: Attribution- \\ NonCommercial-ShareAlike (CC BY-NC-SA)}

Received: October 20, 2021;

Accepted: November 30, 2021;

Published: December 31, 2021;

\begin{abstract}
Soa is a combination of several genealogically territorial eyes of the house. Each Soa usually has a symbol in the form of Totem, which is the identity of each Soa. Soa is still maintained until now. Even every symbol or Totem is still present in implementing traditional ceremonies. This study aimed to discover Soa and its role based on Totem in Negeri Hutumuri, South Leitimur Sub-district, Ambon City. This research is qualitative. The data source was obtained by purposive sampling. The Soa heads and traditional elders were used as informants. Data collection techniques through interviews, participatory observation, and documentation. The results of the study show: 1) Soa in the life of the people of Negeri Hutumuri consists of 5 Soa, namely Soa Pattihutung, Soa Mokihutung, Soa Tutupasar, Soa Lapaut, and Soa Puasel. 2) The role of each Soa is based on the Totem: 1. Soa Pattihutung, with the symbol of the Soa pigeon is role as an honest leader in leadership (King); 2. Soa Mokihutung symbolizes the Soa Mangole bird in charge of maintaining maritime security (Kewang sea/marine police). 3. Soa Tutupasar with the symbol of Soa, namely Soa-Soa, in charge of maintaining forest security (Kewang land/forest police). 4. Soa Lapaut, with the symbol of the Soa snake, is in charge of maintaining security and order (police/soldiers). 5. Soa Puasel, with the symbol of the Soa frog maintaining the cleanliness of water and art in the Negeri Hutumuri.
\end{abstract}

Keywords: Hutumuri; Maluku; Soa; Totem; Traditional Elders

Copyright (C) 2021. Owned by Author(s), published by Society. This is an open-access article under the CC-BY-NC-SA license. 


\section{Introduction}

Maluku is part of the Unitary State of the Republic of Indonesia which has thousands of islands and is inhabited by various tribes, religions, languages, and cultures (Ufie et al., 2020). Therefore cultural diversity in Maluku is a historical and social fact that no one can deny. The uniqueness of these diverse cultures has implications for the mindset, behavior, and personal character as a living tradition in society (Matitaputy, 2019).

In one traditional village/land in Maluku, especially in Ambon Island and Central Maluku, a King usually leads it. As the head of the traditional land, the King is assisted by Soa heads appointed by members (Soa's child) (Tunny \& Tomia, 2018). In carrying out his government duties, the Soa head helps the King according to their turn when the King is not in place. The head of the Soa who gets their turn in the task is called the head of the Soa guard (Latuconsina et al., 2020) or the head of the Soa month or Bapa Jou (Alfredo, 2011).

The structure of the state government is a legacy of the Dutch Government where this traditional law system as stipulated in the Landraad Amboina Decree No. 14 of 1919; it is stated that the Negeri Government is regent en de heads of Soa. Furthermore, in the decision of Landraad Amboina No. 30 of 1919, it is stated that the negorij bestuur is regent en de heads of Soa, which means that the implementation of the government of the Negeri is carried out by the King and the heads of Soa (Latuconsina et al., 2020).

The King or leader of traditional land is usually based on a certain lineage and comes from the eyes of the Parental house in the Soa Parenta/order (Alfredo, 2014). Soa heads are representatives of each Soa in one Negeri. This research sees that in Maluku culture, every traditional land has a Soa consisting of at least two Soa and a maximum of nine Soa. Each Soa has duties and functions according to the Soa symbol.

Ties between Soa members in several Negeri or villages are usually marked as part of their ancestry. According to Asare et al. (2014), each member of the totemistic group has the same ties and aspirations with colleagues and has the same designation. Totemism in anthropology generally states that each social group is identified with a particular species (Pasaribu \& Permana, 2017).

In the life of the people of Negeri Hutumuri, each Soa has a special animal symbol (Totem) that represents the role and function of each Soa or clan. This is in line with Alfons (2020), which states the existence of totemism in the Hutumuri people by considering the Totem as Soa's symbol. This existence seems to have shown a self-identity from each Soa through the totems on the clothes, the stickers affixed to the doors or windows, and public vehicles. Each Soa always appears with its Soa symbol at every traditional ceremony. Special symbols such as Soa Lapaut with the symbol of Soa snake, and Soa Puasel with the symbol of Soa frog.

Of course, modern life questions the existence of a totem belief that is very difficult to maintain. In reality, the presence of the Totem itself on Ambon Island for the Leitimor peninsula of the Ambon Island community is only found in the Negeri Hutumuri. Negeri Hutumuri is located on Ambon Island, which has experienced a touch of modern world development but still maintains the customs and culture of totemism beliefs that have existed since ancestral times (Alfons, 2020). This is an interesting study because of the uniqueness of the indigenous people who live in the Negeri Hutumuri, which still maintains Soa's existence with its role according to the existing Totem and is not owned by other Negeri on the island of Ambon. This research is very important for the people of Ambon Island, especially the younger generation in Negeri Hutumuri, to maintain the existence of local culture as a form of local wisdom. This study aimed to discover Soa and its function based on the Totem symbol in Negeri Hutumuri, South Leitimur Sub-district, Ambon City.

Copyright ( ) 2021. Owned by Author(s), published by Society. This is an open-access article under the CC-BY-NC-SA license. 


\section{Literature Review}

\subsection{Soa in Maluku People Life}

The term Soa comes from Tidore, which is taken from the name of the former capital (in 1960), namely Soa-Siu, which means "nine Soa". The term indigenous given by the Ambonese island community in Negeri Allang Soa is called Uru. In Erie, it is called Antoun (Cooley, 1987). According to the Hutumuri community, Soa comes from Sual, separated or divided. Of course, what is meant is the various clans or eyes of the house, which then decide to merge into one Soa.

The background of the existence of Soa existed before the formation of a single Negeri, namely when the process of population movement continuously and gradually filled petuanan (one area). They settle down, and when they feel the same way, several house eyes join themselves in a small fellowship and live together. Soa is a combination of several units of the house or clan. Soa itself is a combination of several units of the house or clan (family) and from several Soa then merged into one Hena/Negeri/village (Matitaputty \& Masinay, 2020). The same thing was expressed by Cooley (1987) that Soa is a collection of unilateral hereditary groups, i.e., houses that are formed at a certain time and enlarge when new arrivals are added and decrease when there are extinct houses. Soa plays an important role in developing a Negeri (village) (Matitaputty \& Masinay, 2020).

The number of Soas found in one Negeri varies. Still, the research finds that there are at least two Soa in Noloth and the Nuaulu tribal community in Tamilou (Matitaputty, 2016), three Soa (Nendissa, 2010), four Soa in Negeri Oma (Matitaputty \& Masinay, 2020). There are also five Soa in Mornaten (Touwe et al., 2020), five Soa in Haruku (Asrul et al., 2017), six Soa in Porto (Matitaputty, 2018), eight Soa in Negeri Allang (Matitaputty, 2013), and nine Soa in Negeri Ihamahu and Booi (Matitaputty, 2018). All information shows that the number of Soa in each village/traditional land in Maluku is different.

Soa is led by a Soa head who is in charge of assisting the King (King: the name for the leader of a Negeri/village in Maluku) in carrying out the Negeri government on behalf of Soa. The head of Soa has a strategic role in the government of the Negeri/village as a communication bridge between the King and the children of Soa (Soa community/Soa members). The head of Soa serves as a communication bridge between Soa members and the village government and, at the same time, as a representative who represents Soa in village-level decision making. If there is something important that the Soa children (members) need to know, the head of Soa will gather the Soa children (Soa members) through an oral invitation delivered by someone appointed (Kaliky et al., 2015). For example, when carrying out the demolition and closing of the traditional house (Baeleo), after a Saniri Negeri meeting was held, the King asked the head of the Soa to inform the children of the Soa. The head of Soa will ask Marinyo to inform Soa's children to gather at the Head of Soa's house to discuss various Soa preparations for the demolition and closure of Baeleo.

In practice, the existence of Soa and its role in several Negeri in Maluku is currently reemerging after the re-enactment of Law No. 32 of 2004 concerning Regional Administration and followed by Regional Regulation of Maluku Province No. 14 of 2005 concerning Redetermination of the Negeri as Traditional Law Community Unit in the Maluku Province area. The enactment of these two laws replaces Law No. 5 of 1979 concerning the Village Government. Implementing the law raises the problem of the loss of traditional existence, including Soa (Dokolamo, 2021). This law changes the structure of traditional government in Maluku from the King government system to a village head, Village Community Resilience Institute and Village Mediation Institute replace Saniri, including Soa, Kewang, Marinyo, and Maueweng (Matitaputty, 2018). 


\subsection{Totem as a symbol and clan identity}

The Totem appears in three distinct manifestations: 1) in the actual entity in the physical world that the Totem group believes to be its ancestor; 2) in man-made images of Totem carved into wood or stone, for example, and used in related ceremonies; 3) on the actual human members of the Totem group itself (Riley, 2014). The term Totem appears in ethnography towards the 18th century. This word appears in the interpretation of Indian, J. published in London in 1791 (Asare et al., 2014). The word Totem was introduced by Mc. Lennan (1869-1870) comes from the word o toteman, which means family or relatives (Wonmut, 2017). The meaning of the word Totem, which entirely reads ototeman, in Ojibwa language means "he is my male relative" (Widana et al., 2016).

Durkheim found the symbols of the Totem animal to be very meaningful to the clan who worshiped it because the animal was considered a sacred part and was an embodiment of the sacred and a perfect example of the sacred (Widana et al., 2016). According to Durkheim, Totem is a symbol of the clan itself, related to the power behind it, according to the above view. Totem is also a symbol of cohesion and social identity because the Totem unites each clan member in a special bond that is not based on a blood relationship (genealogy) (Widana et al., 2016). Furthermore, according to Dandirwalu (2014), the basis of the special bond of clan members is because they have the sa me name (taken from the names of something material, especially animals and plants), which the clan considers to have kinship/family relations. As a clan symbol, the Totem immediately refers to the clan's identity (clan identity).

Each clan member will give meaning to the symbol concerning its identity. The Totem symbol revives solidarity and moves clan members to participate in collective life (Dandirwalu, 2014). The Totem is something concrete, the real picture of a clan, so the Totem is an identification mark in a group or clan that is similar to an identification badge to show that identity (Sopacoly et al., 2019)

The name or symbol worn on a clan is not just a word but a being, and it is an essential part (Durkheim, 2011). Each clan in Maluku has its Totem, which is taken from animals and plants. Totems in Maluku in several regions are based on their respective clans and bind each clan.

\section{Research Methodology}

This research uses qualitative research. Qualitative research design produces descriptive data and data analysis and interpretation in written or spoken words from people and observed behavior (Creswell \& Poth, 2017). This study describes the research object about Soa existence and its role following the Totem symbol of the Soa that exists in the life of the people of Negeri Hutumuri. The researcher becomes the key instrument, and the data source is chosen purposively. Namely, the informant is the person who is considered to know best what is being studied so that he can open the door wherever the researcher collects data (Sugiyono, 2015). In this study, the informants consisted of five heads of Soa, namely the head of Soa Pattihutung, the Head of Soa Mokihutung, the Head of Soa Tutupasar, the Head of Soa Lapaut, and the Head of Soa Puasel. The time for the research to take place is from February to March 2021.

Direct observation, interviews, and documentation collected data. The collected data was analyzed interactively until it reached saturation point using flow research analysis techniques (Miles, 1992). Data analysis activities include three elements: first, data reduction, which is part of the analysis of sharpening, classifying, directing, removing unnecessary, and organizing data in such a way that conclusions can be drawn and verification of data presentation and conclusion drawing (Matitaputty \& Masinay, 2020) 
Second, data presentation, namely all data obtained in the form of field notes made in the form of narrative text at each point that has been reduced in the matrix. Third, concluding the emergence of Soa in the indigenous people of the Negeri Hutumuri, analyzing the existence of Soa and their functions according to the totem symbol of each Soa and the future of Soa in Negeri Hutumuri.

\section{Results and Discussion}

\subsection{Totem Manifest}

As stated by Riley (2014), Totem appears in three different manifestations, namely: (1) in actual entities in the physical world which the Totem group believes to be their ancestors; (2) in man-made images of Totem carved into wood or stone for example and used in related ceremonies; (3) and on the actual human members of the Totem group itself. Answering Riley's view regarding the manifestation of the emergence of Totem, in Negeri Hutumuri, the emergence of Totem not only answers one of the three views, but the manifestation of the emergence of Totem in Negeri Hutumuri answers the three views of Riley.

1) Totemism is a religion that believes a certain ethnic group is related to ancestral spirits (Maryone, 2011). The Hutumuri people also believe that the Totem symbol in each Soa embodies their ancestors. Each Upu Latu or Soa leader has their magic, and the proof of this magic is their ability to change their physical form into special animals. The animals referred to are only certain types and have special characteristics through a red cloth bond (kain berang) on one part of their body, considered an ancestor or ancestor (Alfons, 2020).

The magical properties of each Upu Latu include Upu Latu Siti Pattiteru from the eyes of the Waas house, leading the Hena Pattihutung to transform into a pigeon. Upu Latu Sekuku Daging from the eyes of the Pattiapon house leads Hena Mokihutung whose magical form can change into a Mangole bird. Upu Latu Surinay from Pesurnay's house's eyes leads Hena Tutupasar, whose magical form can change into a flying Soa-Soa (monitor lizard). Ina Latu Sibundaraya from the eyes of the house of Horhoruw leads the Hena Puasel, whose magical form can change into a frog. Meanwhile, Upu Latu Yana Puty, from the eyes of the Sameaputty house, leads the Hena Lapaut, whose magical form can transform into a snake (Alfons, 2020).

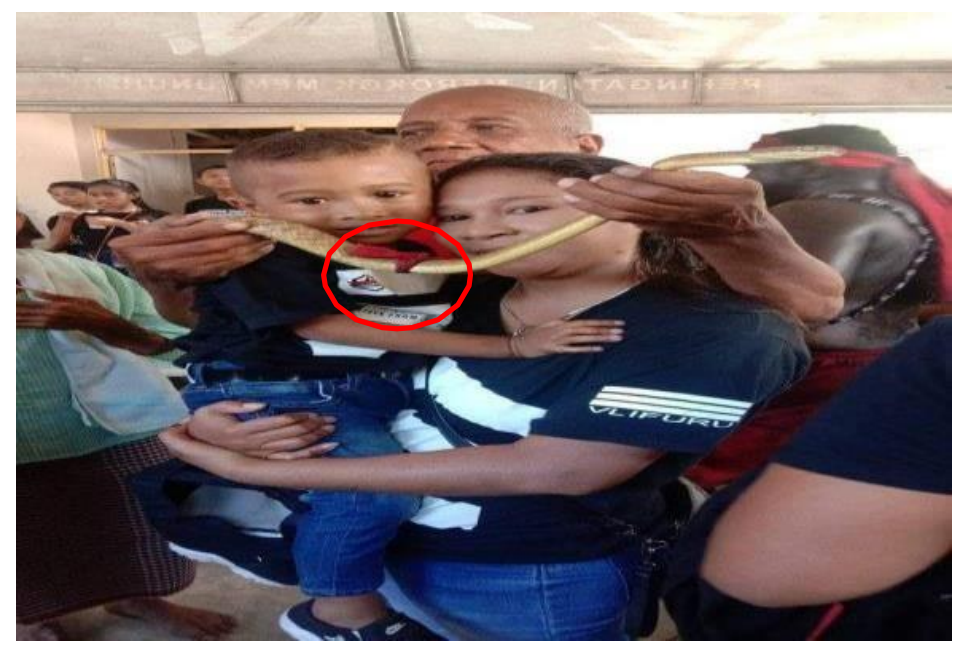

Figure 1. The symbol of Soa Laput (Snake) which is marked with a red kain berang

2) Man-made images of Totem carved into wood or stone, for example, and used in related ceremonies. This can be seen in Negeri Hutumuri, where Soa's symbol is depicted on the 
walls of the Baeleo Suluwaming of the Negeri Hutumuri and every Soa pillar in the Baeleo. Baeleo is seen as an old house or ancestral house because it is considered a connection as the first residence of a group of people who first arrived and are considered the Negeri's founders (Salhuteru, 2015).

The identity of the Totem can also be found from the screen printing of black clothes commonly used in traditional ceremonies, stickers affixed to doors or windows of houses, and public transportation belonging to the Hutumuri community. Concerning the relationship between the Totem and their owners, the implementation of the ritual creates a deep unity between the Totem owners (clan members) and their ancestors who are present in the form of the Totem creatures concerned (Wonmut, 2017).

This can also be seen in Negeri Hutumuri, wherein the life of the Hutumuri people come alive by always presenting the Totem symbol directly at traditional ceremonies. Such as the symbols of Soa Lapaut (Snake), Soa Puasel (Frog), and Soa Pattihutung (white pigeon). Unlike the three Soa, the other Soa, Soa Mokihutung (Mangole bird) and Soa Tutupasar (Soa-Soa), are rarely presented. This is in line with the diminishing role of the two Soa in the people of Negeri Hutumuri as Coastguards (Sea) and Forests.

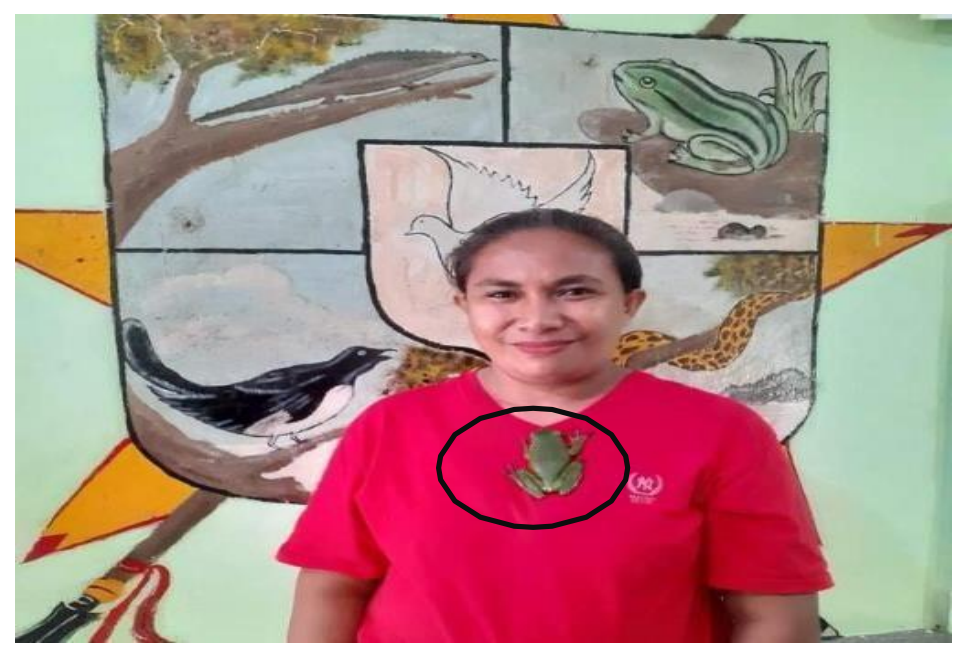

Figure 2. Soa Puasel Member with Soa Frogs attached to clothes

3) As a member of the totem group. Each clan in the Indigenous people of the Negeri Hutumuri is incorporated into one of the five existing Soa (including the eye of the house or the clan of immigrants who later join the Soa Puasel). Thus, every community member is included in the totem group in the Negeri Hutumuri community (can also be seen in Table 1).

This is very clearly seen during the implementation of traditional rituals. Each community takes part in its respective Soa. At the end of the traditional ceremony, each Soa member will be in the Patita meal at their respective Soa house. The implementation of eating Patita in Maluku means eating together is always carried out during traditional ceremonies (Matitaputty \& Masinay, 2020). 


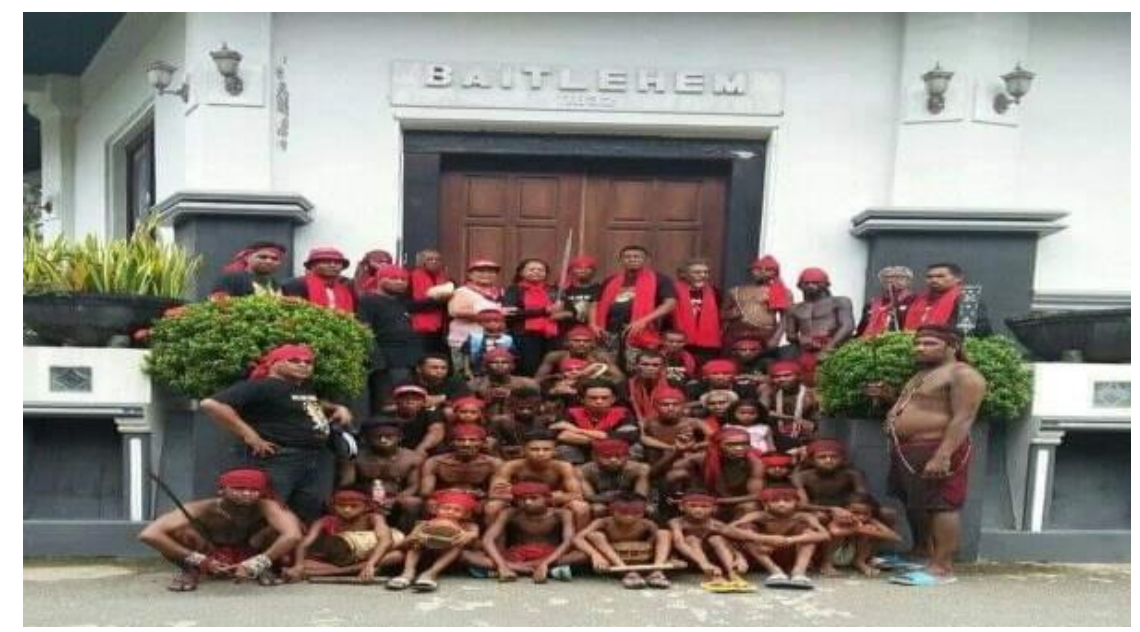

Figure 3. Member of Soa Lapaut after the traditional ceremony of the inauguration of the King

\subsection{Soa in the life of the Traditional people of the Negeri Hutumuri}

The social life of the Negeri Hutumuri people has a standard social structure, which is divided by lineage. In general, the social structure of the Hutumuri community is divided into five Soa, with each leader, duties, and responsibilities as the integrity of the Negeri (Muskitta, 2015). The structure can be explained as follows:

\subsubsection{Soa Pattihutung}

Soa Pattihutung formerly occupied the Ama Putut area (approximately $2 \mathrm{Km}$ from the present Negeri of Hutumuri). Previously, this Soa was led by Ina Latu Siti Patiteru (Marga Waas) (Hetharion \& Matitaputty, 2013) so Soa Pattihutung bequeathed descendants to the Waas clan. There are ten clans in this Soa: Waas, Leiwakabessy, Matakena, Paays, Matuankotta, Lekahatu, Lesiasel, Salhuteru, and Arlawelang. But for the eyes of the house of Lekahatu, Salhuteru and Arlawelang are no longer in the Negeri of Hutumuri (extinct). This Soa has the task of taking care of matters related to government and is symbolized by the white pigeon (Muskitta, 2015).

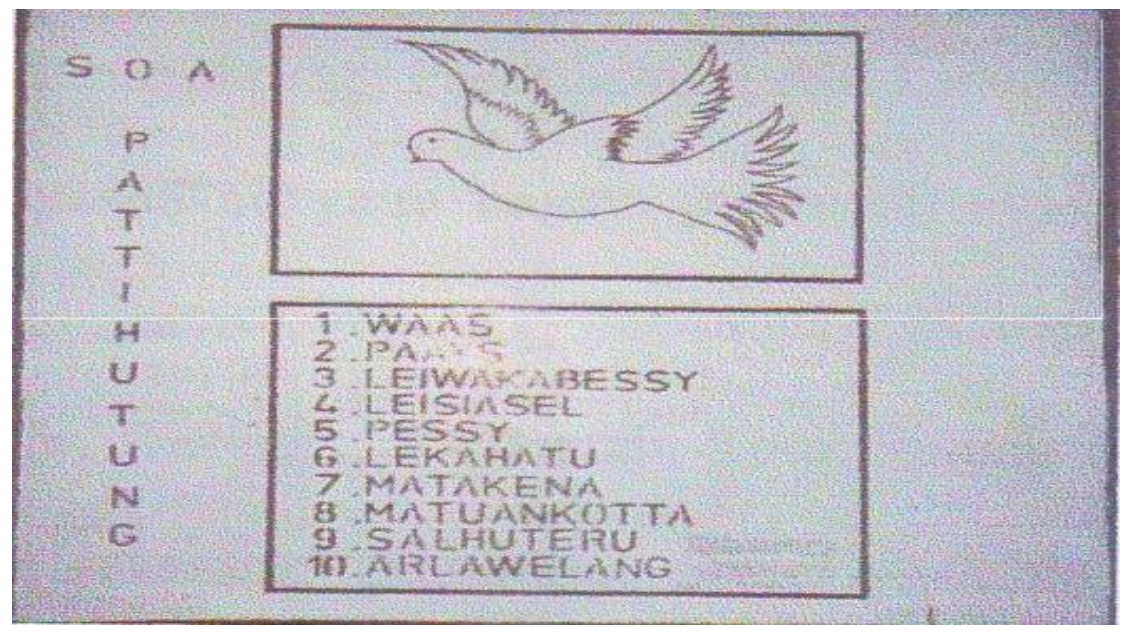

Figure 4. Symbol and clan of Soa Pattihutung (Matitaputty, 2013; Hetharion \& Matitaputty, 2013) 


\subsubsection{Soa Mokihutung}

Soa Mokihutung used to be located in the mountainous area of Ehud (approximately $4 \mathrm{~km}$ from present-day Hutumuri). Formerly the leader of this Soa was Upu Latu Sekuku Daging (Pattiapon). There are six clans in this Soa, namely: Pattiapon, Tehupeiory, Souripet, Tepalawatin, Kappuw, and Pattiasina (Alfons, 2020). Soa Mokihutung bequeaths descendants to the Pattiapon clan who is in charge of maintaining security at sea, and the symbol of this Soa is the Mangole bird (Muskitta, 2015).

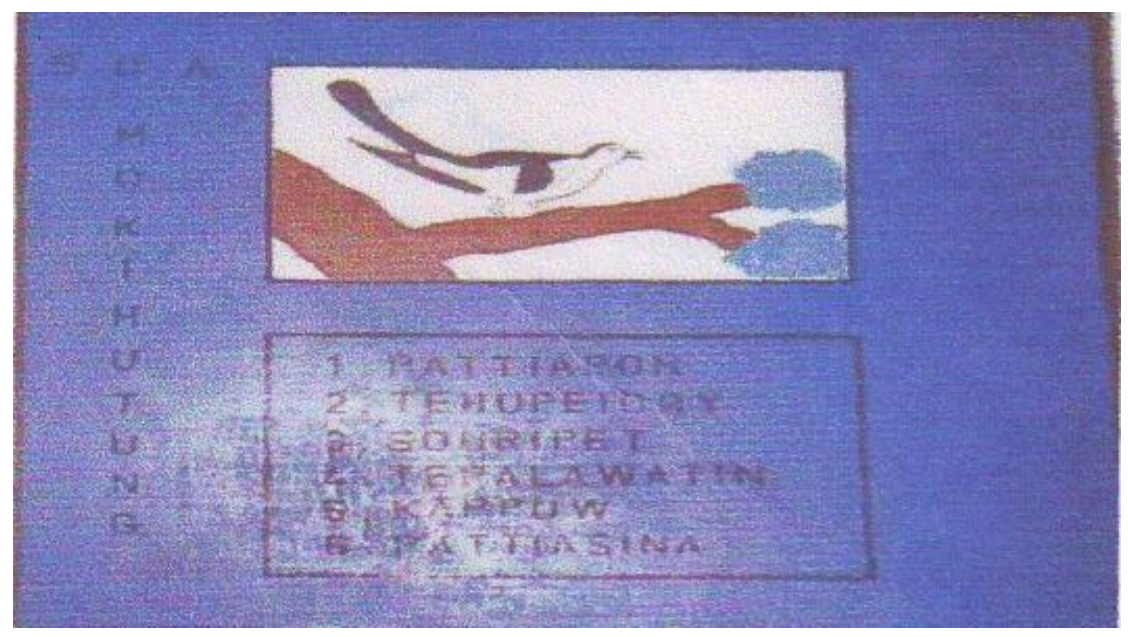

Figure 5. Symbol and clan of Soa Mokihutung (Matitaputty, 2013; Hetharion \& Matitaputty, 2013)

\subsubsection{Soa Tutupasar}

In the past, Soa inhabited the Totu area, approximately $1.5 \mathrm{Km}$ from Hutumuri today. This Soa was led under Upu Latu Surinai (Pesurnai). There are eight clans in this Soa, namely: Pesurnay, Lewaherilla, Thenu, Asthenu, Pattihahuan, Harmusial, Tomalueng, Pistaut (Hetharion \& Matitaputty, 2013). The Tomalueng clan currently occupies the Petuanan area of the Negeri Passo. In contrast, the Pistaut clan has begun to disappear (extinct) in the eyes of the house in the Negeri Hutumuri because there is no longer a lineage. Soa Tutupasar bequeathed offspring to the Pesurnay clan, which regulates the community's economy, with this Soa symbol being Soa-Soa (Alfons, 2020).

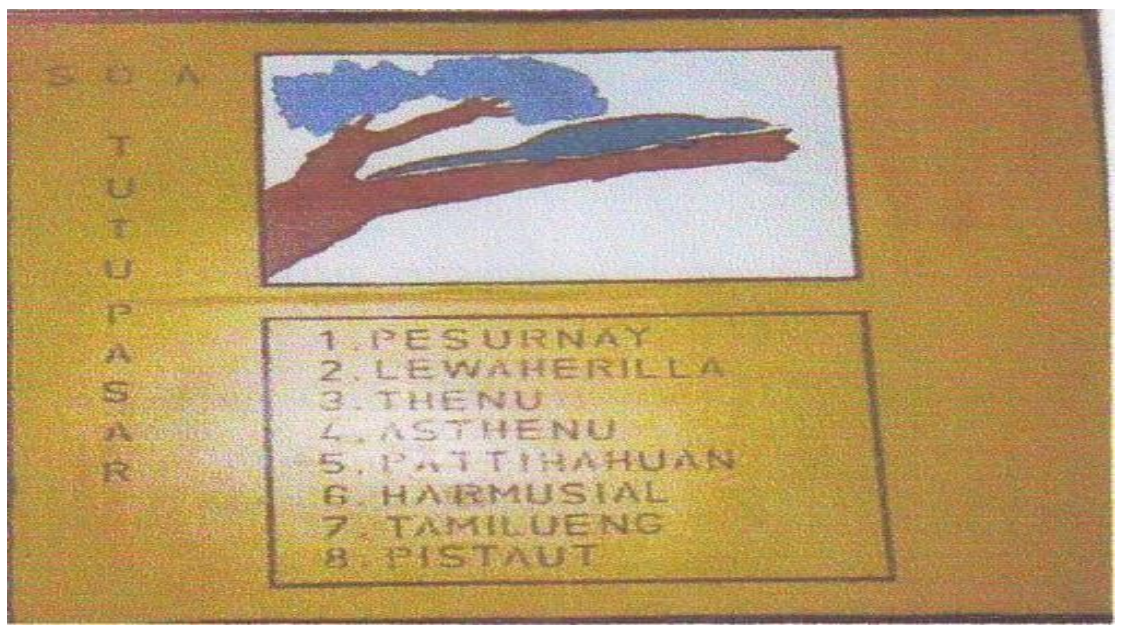

Figure 6. Symbol and Clan of Soa Tutupasar (Matitaputty, 2013; Hetharion \& Matitaputty, 2013)

Copyright (C 2021. Owned by Author(s), published by Society. This is an open-access article under the CC-BY-NC-SA license. 


\subsubsection{Soa Lapaut}

In the past, this Soa occupied the area of Mount Tomol, approximately $8 \mathrm{~km}$ from Hutumuri today. The leader of this group is Upu Latu Sitania Pessy/Upu Latu Yana Putty (Sameaputty). There are five clans contained in this Soa, namely Sameaputty, Souhuwat, Kailuhu, Lilipory, and Patalala (Alfons, 2020). Soa Lapaut bequeathed descendants to the Sameaputty clan. The task of this Soa is to maintain order and security and is symbolized by the snake.

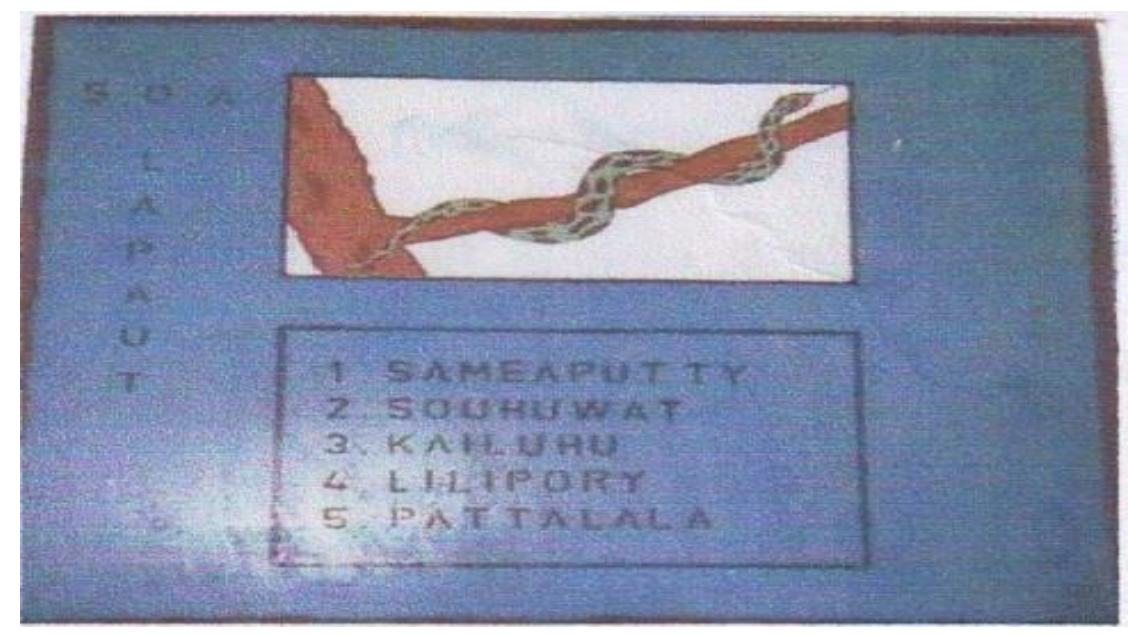

Figure 7. Symbol and clan of Soa Lapaut (Matitaputty, 2013; Hetharion \& Matitaputty, 2013)

\subsubsection{Soa Puasel}

In the past, Soa inhabited the area of Mount Nusuruman, approximately $2 \mathrm{~km}$ from Hutumuri today. Upu Latu Sumbarala, previously led Soa. Soa's symbol is a frog. In the past, there were five clans in this Soa, namely Horhoruw, Moniharapon, Matuahitimahu, Rehatalanit, Hursepuny, and now it is increasing because all the new clans that inhabit the Negeri Hutumuri are included in Soa Puasel or called Soa immigrants (Alfons, 2020). This Soa bequeathed descendants to the Horhoruw clan, whose job was to protect water sources and regulate the arts. This Soa is the frog/toad symbol (Muskitta, 2015).

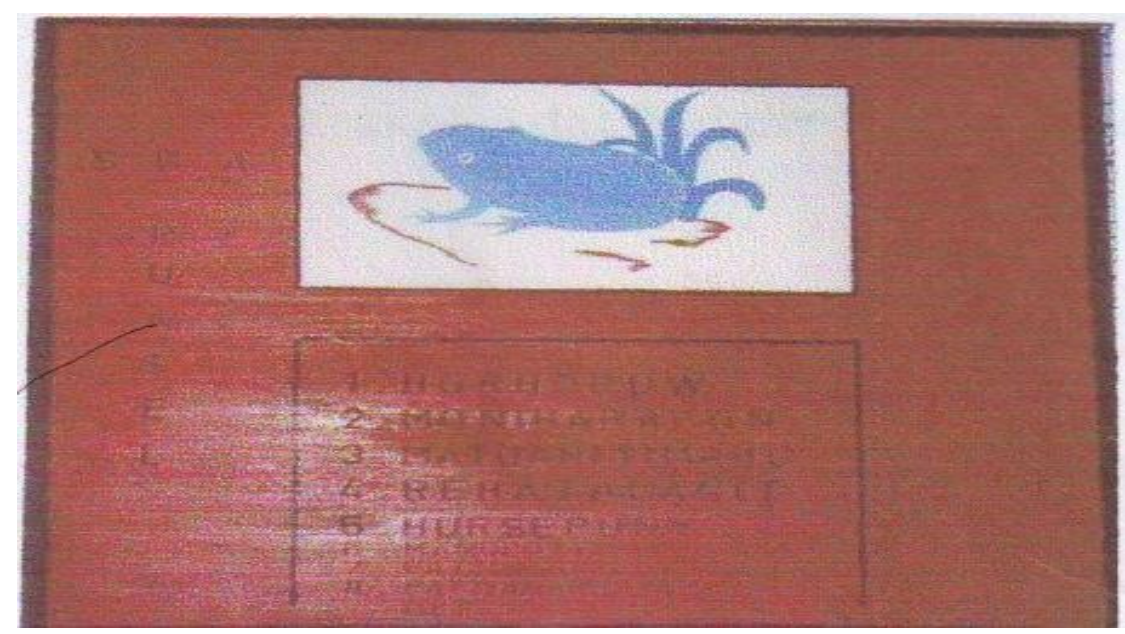

Figure 8. Symbol and Clan of Soa Puasel (Matitaputty, 2013; Hetharion \& Matitaputty, 2013) 
For more details about the types of Soa, the eye of the house in Soa, the name of the teong/teun, the status, and the symbol of each Soa Negeri Hutumuri, can be seen in the following table.

Table 1. Soa Name, Eye of House, Teun/Teong, Status, Characteristics, and Symbol of Totem

\begin{tabular}{|c|c|c|c|c|c|}
\hline No & Soa Name & $\begin{array}{l}\text { Eye of House } \\
\text { (Clan/Family) }\end{array}$ & $\begin{array}{l}\text { Teong/Teun } \\
\text { (Traditional } \\
\text { Name/Title) }\end{array}$ & Status & $\begin{array}{l}\text { Totem } \\
\text { Features }\end{array}$ \\
\hline 1 & Pattihutung & $\begin{array}{l}\text { - Waas } \\
\text { - Matuankotta } \\
\text { - Leiwakabessy } \\
\text { - Matakena } \\
\text { - Lesiasel } \\
\text { - Pessy } \\
\text { - Paays } \\
\text { - Arlawelang }\end{array}$ & $\begin{array}{l}\text { - Leruhu } \\
\text { - Titimula } \\
\text { - Leruhu } \\
\text { - Leruhu } \\
\text { - Matita } \\
\text { - Leruhu }\end{array}$ & $\begin{array}{l}\text { - Head of Soa Parenta } \\
\text { - Head of Traditional Soa } \\
\text { - Member } \\
\text { - Member } \\
\text { - Member } \\
\text { - Member }\end{array}$ & $\begin{array}{c}\text { Pigeon } \\
\text { (Announcer) } \\
\text { / Leader }\end{array}$ \\
\hline 2 & Mokihutung & $\begin{array}{l}\text { - Tehupeiory } \\
\text { - Pattiapon } \\
\text { - Pattiasina } \\
\text { - Kappuw } \\
\text { - Soripet } \\
\text { - Tepalwatin }\end{array}$ & $\begin{array}{l}\text { - Timu-timu } \\
\text { - Pesiwa } \\
\text { - Timu-timu } \\
\text { - Timu-timu } \\
\text { - Timu-timu } \\
\text { - Louputu }\end{array}$ & $\begin{array}{l}\text { - Head of Soa Parenta } \\
\text { - Head of Traditional Soa } \\
\text { - Member } \\
\text { - Member } \\
\text { - Member } \\
\text { - Marinyo }\end{array}$ & $\begin{array}{l}\text { Mangole Bird } \\
\text { (preserving } \\
\text { life on the } \\
\text { beach) (Sea } \\
\text { guard) }\end{array}$ \\
\hline 3 & Tutupasar & $\begin{array}{l}\text { - Lewaherilla } \\
\text { - Thenu } \\
\text { - Pesurnay } \\
\text { - Asthenu } \\
\text { - Pattihahuan } \\
\text { - Harmusial }\end{array}$ & $\begin{array}{l}\text { - Tersili } \\
\text { - Tersili } \\
\text { - Tuilatu } \\
\text { - Tersili } \\
\text { - Pikalessy } \\
\text { - Tinilisa }\end{array}$ & $\begin{array}{l}\text { - Head of Soa Parenta } \\
\text { - Head of Traditional Soa } \\
\text { - Member } \\
\text { - Member }\end{array}$ & $\begin{array}{l}\text { Soa-Soa (fly) } \\
\text { (preservation } \\
\text { of forest } \\
\text { resources) } \\
\text { (Forest Police) }\end{array}$ \\
\hline 4 & Puasel & $\begin{array}{l}\text { - Horhoruw } \\
\text { - Moniharapon } \\
\text { - Rehatalanit } \\
\text { - Matuahitimahu } \\
\text { - Other }\end{array}$ & $\begin{array}{l}\text { - Pourisa } \\
\text { - Tokomahu } \\
\text { - Pourisa } \\
\text { - Pourisa }\end{array}$ & $\begin{array}{l}\text { - Head of Soa Parenta } \\
\text { - Head of Traditional Soa } \\
\text { - Member } \\
\text { - Member } \\
\text { - Member }\end{array}$ & $\begin{array}{c}\text { Frogs } \\
\text { (guarding } \\
\text { water and art) } \\
\text { (Managing } \\
\text { art) }\end{array}$ \\
\hline 5 & Lapaut & $\begin{array}{l}\text { - Kailuhu } \\
\text { - Souhuwat } \\
\text { - Sameaputty } \\
\text { - Patalala } \\
\text { - Lilipory }\end{array}$ & $\begin{array}{l}\text { - Siloi } \\
\text { - Leihitu' } \\
\text { - Lisapali } \\
\text { - Titimula } \\
\text { - Pesune }\end{array}$ & $\begin{array}{l}\text { - Head of Soa Parenta } \\
\text { - Head of Traditional Soa } \\
\text { - Malesi }\end{array}$ & $\begin{array}{l}\text { Snake (guard, } \\
\text { Negeri guard) }\end{array}$ \\
\hline
\end{tabular}

Source: Matitaputty (2013); Muskitta (2015); and research collaboration

\subsection{Soa Functions based on the Soa Symbol (Totem) in Negeri Hutumuri}

Biological cultural resources are important for traditional communities for food, medicine, and cultural life. In Indonesia, we find a lot of local wisdom that comes from biological culture, both flora, and fauna. Many animals have an important value in ceremonies. In Toraja, buffalo are sacrificed at funeral parties to accompany the spirits of the dead in a Rambu Solo ceremony because the Toraja people think that buffalo is a vehicle ridden by the spirit of the deceased to take them to heaven (Bunga et al., 2020)

Buffaloes in Tenganan Pegringsingan Village are not used as working animals. Still, buffaloes are privileged, used in special ceremonies to become adored and respected animals. 
Even buffalo are very close to humans and are categorized as Totem (Widana et al., 2016). Many tribes honor certain animals, which they believe to be symbols or totems of the tribe. This can also be seen in the people of Negeri Hutumuri. They, until now, hold firmly to their belief that certain animals in every Soa in this Negeri have the value of local wisdom that is very deep as a part of their lives. However, some of them are currently experiencing a decline in their traditional Totem wisdom value.

Soa Pattihutung, Pati; means lord, and hutung (Hutong) means many. So Pattihutung means many masters. Following its means, the master, in this case, the King or leader of the Negeri, comes from Soa Pattihutung. This Soa functions to run the wheels of government. Following the Soa symbol, which is a pigeon symbol by taking a white character, the pigeon's wings are stretched, and when they are flapped, they will form waves (Vannesa \& Anggraeni, 2020). White symbolizes purity, cleanliness, and loyalty, meaning the value of wisdom. A king who leads this Negeri must be loyal, sincere, and honest in carrying out his duties to serve his people.

Pigeon is also known to be able to bring prosperity and peace. Several symbols have been used throughout history as symbols of peace, and the most famous is the pigeon (Asy'ari et al., 2020). The pigeon is a symbol that brings peace (Vannesa \& Anggraeni, 2020). Thus a king must carry out his duties properly for the progress and welfare of society in peace. In addition, pigeons live in pairs and live in groups (Aji et al., 2015) which is also expected from the King's figure who does not live for his own sake but for the welfare of his people.

Pigeon does not have bile. Bile symbolizes bitterness, meaning that it can be believed that there is no bitterness in the pigeon (Bailey, 2020). It is hoped that a leader or King should not hold a grudge against his people. The flapping of its wings depicts the leader's figure who has always been a protector for the people. Lastly, the pigeon is a very smart bird. Pigeon finds their way back to the cage when they are flown in two steps: determining the cage's direction and using a solar compass to fly to the cage. When pigeons cannot see the sun, they use a magnetic compass (Dahrun et al., 2019).

Pigeons can see and recognize well every landscape they pass. From there, the pigeons can predict their location relative to their cage or place of origin. This ability is also complemented by the pigeon's ability to associate a location with that place's smell and wind conditions. This ability is very useful for pigeons to remember a place they have traveled for the first time (Zebua et al., 2016). This is for maintenance, of course, making the role of pigeons as postal pigeons (Dahrun et al., 2019). Postal pigeons have been trained to deliver letters or messages (Nurdiyanto \& Yanti, 2019). It is hoped that a King will become a carrier of good message for the people of Negeri Hutumuri. The great hope of a king is of course not only smart but also wise in leading and making decisions and able to bring progress to his Negeri.

Next is Soa Mokihutung. From the origin, the word Moki means more, and Hutung (Hutong) means a lot, so Mokihutung means more and more. The function of this Soa is to maintain the safety of the sea. Following the Soa symbol, the Mangole bird has the nature of always protecting nature around the beach and ocean. The Mangole bird is known as a loyal bird. If in the seasons, it will go to the beach where it usually lays eggs (will not move to other coasts) and return when the eggs hatch. It is hoped that Soa Mokihutung has a role like marine police who controls marine security and even controls the existence of natural resources to be guarded, managed, and conserved to continue the existing ecosystem. Of course, the continuity of the ecosystem will affect human survival as the main user of the natural resource. Kewang is an officer who has the role of guarding everything in the seas of the Negeri Hutumuri for the sustainability of the generations that exist in the Sasi culture in Maluku. In Kei Besar the term Sasi is known as Yot 
and Kei Kecil as Yutut (Suntoko et al., 2019). In its implementation, the Sasi is divided into two parts, namely the land Sasi (Forest) and the sea Sasi (Ellen, 2016).

In Maluku Province, Indonesia, natural resources are managed under a locally defined set of rules and regulations known as Sasi (Matitaputty et al., 2018). Sasi was revived as community-based management, as environmental wisdom applied to sustainability issues (Ellen, 2016). The local wisdom of Sasi culture in Maluku is interpreted to maintain ethics in community life. Natural commercial plants are limited to a certain period to maintain the balance of nature and other ecosystems. This results in natural resources being preserved to support the people's lives in them (Matitaputty et al., 2018).

The existence of Sasi makes the community orderly in maintaining the survival of natural resources because the extraction is very concerned with the sustainability of natural resources to ensure the life of each generation. Besides that, the sea is maintained and protected to avoid abrasion, clean, and free from garbage. However, it is regrettable that in the last few decades, the traditional existence of Sasi culture has been abandoned by the people of Negeri Hutumuri. The function of the Kewang as Sasi executor, whose role has been less visible both in the government structure and in real life. Thus, Sasi can answer the goal of today's modern world to live in harmony with nature, as suggested by (Ellen, 2016). The role of local resource management institutions, generally described in the Maluku islands as Sasi, has been adapted to modern goals. Therefore, Sasi needs to be revived as community-based management, as environmental wisdom is applied to sustainability issues (Ellen, 2016).

Today, this is a significant concern for the Hutumuri people to revive Sasi in responding to global challenges in maintaining survival. It can be seen that the abrasion level that is starting to appear in Negeri Hutumuri is due to the lack of the role of Kewang in protecting the shoreline by breeding mangrove plants that are no longer being noticed/starting to disappear. Many anglers use bombs and other fishing rods that are harmful to the ecosystem. In addition, the largest forest fire that occurred in 2005 destroyed the clove, nutmeg, durian, and pineapple trees which are potential natural resources of the Hutumuri community, indicating that the function of Kewang control is no longer being carried out. It needs to be sustainable because sustainability is crucial to maintaining the quality of environmental life and humans. This challenge can be answered in the form of the local wisdom of the Maluku people through Sasi (Matitaputty, 2018, p. 42).

The role of community local wisdom needs to be revived. It is not uncommon for people to still apply local knowledge with conservation, management, and sustainable exploitation of natural resources. All of this shows that the management of nature, forest, water, land-based on traditional wisdom and local knowledge has sustainability for efforts to preserve the natural environment and support the cultural existence of local social groups (Cholillah, 2017).

Soa Tutupasar, according to the meaning of the word Tutu: bowing and Pasar comes from the word Pasal, which means Gupasa wood, so what is meant by Tutupasar is a resident of a Negeri whose job is to cut Gupasa wood. Function to run the community economy. Following the Soa symbol, Soa-Soa has the meaning of wisdom values like Soa Mokihutung, which plays a role in maintaining sea security. Soa Tutupasar functions to maintain economic stability by managing forests in the Negeri Hutumuri through the control function of a forest clerk in carrying out forest Sasi on plantation products belonging to the community. Public. The financial control function is like the police to control the forest (forest police), control the harbor, or the ocean (marine police) (Matitaputty, 2018).

Related to the management, Harkes \& Novaczek (2002) stated that it must be done in the form of Sasi. Sasi is a conventional resource management system in eastern Indonesia, including

Copyright (C 2021. Owned by Author(s), published by Society. This is an open-access article under the CC-BY-NC-SA license. https://doi.org/10.33019/society.v9i2.358 
spatial and temporal restrictions on harvesting crops, cutting timber, and collecting other products from the forest, tidal zone, or sea area. Sasi has regulations to protect several natural resources such as pineapple, walnut, chempedak, durian, areca nut, nutmeg, and sago leaves (Xiuping et al., 2010). The Sasi prohibition is usually applied to resources such as shellfish (lola), coconut trees, sago groves, fruit or nut-producing trees, sacred land (sacred land), forest areas, and intertidal zones (meti) (Hooe, 2012). Unfortunately, the control function of this Soa, similar to that of Soa Mokihutung, is no longer being carried out. Hence, several years ago, a forest fire resulted in the death of long-lived plants such as cloves and nutmeg due to the absence of the control function of the forest guards. Of course, this is an important concern from Soa Tutupasar and the Negeri Hutumuri's government.

Soa Lapaut, according to the origin of the word Paut for the people of Maluku, is the outer part of food packaging such as peanuts (paut kacang), salak fruit (paut salak), so Soa Lapaut acts as a guard or protector of the entire Hutumuri community. This can be seen from the character of Soa's symbol, which is a snake with physical limitations only by crawling does not hinder its agile movements when on the ground or when climbing. This makes this animal a symbol of tenacity, strength, and agility. Soa Lapaut is to protect all the people of Negeri Hutumuri from any attack. This can be seen from the nature of the snake when it faces an enemy that threatens it, so it quickly pounces its prey. That is the big task entrusted by the Hutumuri people to Soa Lapaut, namely to guard and protect all Soa in Negeri Hutumuri. The implementation of these tasks can be seen in all the implementation of traditional activities in Negeri Hutumuri. Soa Lapaut always performs with the Cakalele dance as Soa's task representation to show their strength marked by machete and Salawaku, which means shields that protect. The representation of this task can also be seen from every movement of the Cakalele Alifuru dance from Soa Lapaut, which describes the fighting speed of a mighty man with machete and Salawaku movements and spears that show their attitude to guard and defend Negeri Hutumuri (Hetharion \& Matitaputty, 2013).

Soa Puasel, according to the presence of frogs/toads that inhabit tall tree trunks and often hide behind leaves, or can usually only be found on the sidelines of rocks in clean and uncontaminated water sources in mountainous areas. A voice that is often heard shouting describes the chorus's harmonious tone. The function of this Soa is to keep the water clean and regulate art.

The two functions of the frog as a representation of Soa Puasel, when viewed from its current existence in Negeri Hutumuri, it seems that regulating the arts is still being maintained in society. The musical orchestra - shellfish (Tahuri) is the only very well-known musical chorus in Maluku preserved by Soa Puasel. The responsibility for this art is given to the lineage (eyes of the house) Horhoruw following the duties and responsibilities in regulating the arts (Muskitta, 2015). Tahuri music art from Negeri Hutumuri is currently one of the music icons of Ambon City, Ambon City of Music awarded by UNESCO in 2019. The Joint Learning Program traditional Tahuri music in 2019 has also been introduced to instill a love of traditional music to the younger generation, namely students in Ambon City.

\subsection{Soa's Future}

The hope that Soa will remain a part of the life of the people of Negeri Hutumuri is a prayer from the people of Negeri Hutumuri. After approximately 20-25 years, the village government system changed the structure of traditional government into a village. At the same time, overhauled the existing cultural traditional order without exception of the Soa traditional social organization until 2004. After issuing local autonomy, the Ambon City Government issued the 
Ambon City Regulation No. 8 of 2017 concerning Negeri. Article 25, paragraph 1 states that the Negeri government includes Saniri. The third paragraph in Article 25 states that the Negeri Saniri, as stated in paragraph 1, includes the head, vice, and secretary who come from one of the elements of Soa representatives.

In chapter 1, article 22 states that Soa is a territorial genealogical association in Negeri and consists of several eyes of houses. Article 23 states that the head of Soa is the head of the territorial genealogical alliance, which is domiciled in Negeri Saniri, and is tasked with assisting the head of Negeri government in the implementation of Negeri government representing Soa. This law certainly provides hope and fresh air for the sustainability of Soa in the future. Although currently the two Soas in Hutumuri, namely Soa Mokihutung and Soa Tutupasar, are experiencing a shift in roles, it is hoped that they will be able to carry out these roles again as part of the hope for future generations.

Maintaining the existence of natural resources both on land and at sea through the implementation of Sasi is now no longer a big task of the Hutumuri government through Negeri regulations that are expected to be carried out again as a sustainability effort for and for our generation. The research hopes that the existence of Soa in Negeri Hutumuri will be maintained in the face of global challenges in the future. Of course, the future of Soa is strongly supported by government regulations that provide the basis for legal power and public awareness to maintain and preserve ancestral cultural heritage through local wisdom in Negeri Hutumuri.

\section{Conclusion}

As a traditional culture that has been known since the past, Soa has a very significant function for the supporting communities who are members of it. This means that the existence of Soa as a social organization that is customary and a cultural heritage that has the value of local wisdom in the Hutumuri community is still maintained. There are five Soas in Hutumuri, including: Soa Pattihutung, Soa Mokihutung, Soa Tutupasar, Soa Puasel and Soa Lapaut. Soa is not just a gathering place for several houses or clans that exist in the life of the Hutumuri community. Still, it becomes a binder and identity through the symbol of each Soa. It is believed to represent the ancestors and has a function that reflects each characteristic of the Totem symbol and is a cultural heritage that continues to be maintained as an important matter and become an inseparable part of the life of the Hutumuri people.

The type of Totem in each Soa in Negeri Hutumuri shows the value of local wisdom based on the function and role of each Soa. This role can be seen in implementing traditional ceremonies in Negeri Hutumuri and in regional events that can even be enjoyed on the international stage. Such as Soa Lapaut with the existence of the Cakalele dance, which is often staged to welcome guests both at the national and international levels, and Soa Puasel with the Tahuri music group orchestra, which is well known on the international stage. Besides that, Soa Pattihutung has a wise leader (King) role. Still, there are two Soa that currently need special attention, namely Soa Mokihutung and Soa Tutupasar, in their duties and responsibilities to protect natural resources in the sea and the forest through the Sasi culture to protect the environment. sustainability of generations in Negeri Hutumuri. The great hope is also through government support through regional regulations that strengthen the existence of indigenous peoples in Negeri Hutumuri and wise leaders (King) in seeing every potential of Soa as an important part of supporting the sustainability of the lives of the people of Negeri Hutumuri. 


\section{Acknowledgment}

The author would like to thank the government of Negeri Hutumuri and all key informants from the five Soa in Negeri Hutumuri. The author also thanks anonymous reviewers for reviews on this article.

\section{Declaration of Conflicting Interests}

The author has declared no potential conflicts of interest concerning the study, authorship, and/or publication of this article,

\section{References}

Aji, D. S., Garnida, D., \& Setiawan, I. (2015). Identifikasi Sifat-Sifat Kuantitatif Merpati Balap Tinggian dan Merpati Balap Dasar Jantan. Students e-Journals, 4(2). Retrieved from https://jurnal.unpad.ac.id/ejournal/article/view/6271

Alfons, C. R. (2020). Totemisme Di Era ModerniSasi (Realitas Masyarakat Adat Negeri Hutumuri Kecamatan Leitimur Selatan Kota Ambon). Komunitas: Jurnal Ilmu Sosiologi, 3(2), 89-100. Retrieved from https:/ / ojs3.unpatti.ac.id/index.php/komunitas/article/view/2884

Alfredo, R. (2011). Lembaga Adat "Saniri" Sebagai Forum Komunikasi Dalam Penyelesaian Masalah Publik Di Ambon. KAREBA: Jurnal Ilmu Komunikasi, 1(3), 335-347. Retrieved from https://journal.unhas.ac.id/index.php/kareba/article/view/314

Alfredo, R. (2014). Peran Saniri sebagai Suatu Forum Komunikasi dalam Penyelesaian Masalah Publik di Ambon. Populis, 2(6), 50-61.

Asare, T. O., Howard, E. K., \& Peligah, Y. S. (2014). The Socio-Cultural Significance of Akan Totemsin Textile Designs: A Means for Preservation of Wildlife in Ghana. The International Journal of Science and Technoledge, 2(6), 155-164. Retrieved from http:/ /52.172.159.94/index.php/theijst/article/view/138988

Asrul, A., Rindarjono, M. G., \& Sarwono, S. (2017). Eksistensi Sasi dalam Pengelolaan Lingkungan Hidup dan Peran Serta Masyarakat di Negeri Haruku Kabupaten Maluku Tengah Propinsi Maluku Tahun 2013. GeoEco, 3(1), 69-81. Retrieved from https://103.23.224.239/GeoEco/article/view/11048

Asy'ari, A., Zahriah, \& Faudy, M. (2020). Penerapan Tema Simbolisme Pada Perancangan Museum Perdamaian Aceh di Banda Aceh. Jurnal Ilmiah Mahasiswa: Arsitektur dan Perencanaan, 4(3), 5-11. Retrieved from http://jim.unsyiah.ac.id/ArsitekturPWK/article/view/11185

Bailey, B. J. (2020). Roh Kudus Sang Penghibur. Zion Christian Publishers.

Bunga, H. T., Kawung, E. J. R., \& Kandowangko, N. (2020). Peran Perempuan Dalam Upacara Rambu Solo Di Lembang Pitung Penanian Kecamatan Rantebua Kabupaten Toraja Utara. HOLISTIK: Journal of Social and Culture, 13(1), 1-17. Retrieved from https:/ / ejournal.unsrat.ac.id/index.php/holistik/article/view/29439

Cholillah, J. (2017). Pengelolaan Hutan Berbasis Budaya Lokal Di Dusun Pejam Kabupaten Bangka: Tim Jarlit Kebudayaan Bappeda Prov.Kep.Bangka Belitung. Society, 5(1), 45-58. https:/ / doi.org/10.33019/society.v5i1.19

Cooley, F. L. (1987). Mimbar dan Takhta: Hubungan Lembaga-Lembaga Keagamaan dan Pemerintahan di Maluku Tengah. Jakarta, Indonesia: Pustaka Sinar Harapan.

Creswell, J. W., \& Poth, C. N. (2017). Qualitative Inquiry and Research Design: Choosing Among Five Approaches (4th ed.). SAGE Publications, Inc. 
Dahrun, M., Langoy, M. L., \& Wahyudi, L. (2019). Karakteristik Gaya Aerodinamika Pada BUrung Merpati (Columba Livia). PHARMACON, 8(3), 679-685. https:/ / doi.org/10.35799/pha.8.2019.29392

Dandirwalu, R. (2014). Totem Ambon Manise: Membongkar Segregasi Teritorial Berbasis Agama di Kota Ambon. Antropologi Indonesia, 35(1), 30-44. https://doi.org/10.7454/ai.v35i1.5511

Dokolamo, H. (2021). Matarumah Parentah Dalam Sistem Pemerintahan Adat Di Maluku. Lani: Jurnal Kajian Ilmu Sejarah dan Budaya, 2(1), 69-81. Retrieved from https://ojs3.unpatti.ac.id/index.php/lani/article/view/2688

Durkheim, E. (2011). The Elementary Forms of the Religious Life: Sejarah Bentuk-Bentuk Agama Yang Paling Dasar. Yogyakarta, Indonesia: IRciSod.

Ellen, R. (2016). Nuaulu Ritual Regulation of Resources, SASI and Forest Conservation in Eastern Indonesia. South East Asia Research, 24(1), 5-22. https:/ / doi.org/10.5367/sear.2016.0290

Harkes, I., \& Novaczek, I. (2002). Presence, performance, and institutional resilience of Sasi, a traditional management institution in Central Maluku, Indonesia. Ocean $\mathcal{E}$ Coastal Management, 45(4-5), 237-260. https:// doi.org/10.1016/s0964-5691(02)00057-1

Hetharion, B. D. S., \& Matitaputty, J. K. (2013). Kajian sistem Nilai Budaya Tari Cakalele. Kementerian Pendidikan dan Kebudayaan Republik Indonesia.

Hooe, T. (2012). "Little Kingdom": Adat and Inequality in the Kei Islands, Eastern Indonesia (Doctoral Dissertation). University of Pittsburgh. Retrieved from http://dscholarship.pitt.edu/11382/

Kaliky, R., Hariyadi, S. S., \& Subejo. (2015). Rekonstruksi Sistem Penyuluhan Pertanian di Provinsi Maluku. Agrica Ekstensia, 9(1), 16-26.

Latuconsina, N., Fretes, J. D., \& Tehuayo, J. (2020). Study of the Role of Customary Institutions in Government Systems in Hitu Lama State, Leihitu District, Central Maluku Regency. Jurnal Ilmiah Tata Sejuta STIA Mataram, 6(1), 96-114. https:/ / doi.org/10.32666/tatasejuta.v6i1.106

Maryone, R. (2011). Totemisme pada budaya asmat. PAPUA: Jurnal Penelitian Arkeologi, 3(1), 51-64. Retrieved from https://jurnalarkeologipapua.kemdikbud.go.id/index.php/jpap/article/view/94

Matitaputty, J. K. (2013). Peranan OrganiSasi Sosial "Soa" dalam Kehidupan Masyarakat Adat di Pulau Ambon (Studi Etnografi di Negeri Hutumuri Kecamatan Leitimur Selatan).

Matitaputty, J. K. (2016). Pendidikan Nilai Sosial Budaya Dalam Keluarga Dan Lingkungan Masyarakat Suku Nuaulu Di Pulau Seram. PEDAGOGIKA: Jurnal Pedagogika dan Dinamika Pendidikan, 4(2), 96-107. https://doi.org/10.30598/pedagogikavol4issue2page96-107

Matitaputty, J. K. (2018). Budaya Sasi Untuk Menunjang Sustainable Living Masyarakat Adat Saparua dan Preservasinya dalam Pembelajaran Ilmu Pengetahuan Sosial di Universitas Pattimura (Doctoral Dissertation). Universitas Pendidikan Indonesia. Retrieved from http://repository.upi.edu/46589/

Matitaputty, J. K., Ali, M., Sjamsuddin, H., \& Maryani, E. (2018). Model of Sustainable Development of Sasi from Maluku, Indonesia. Jour of Adv Research in Dynamical E Control Systems, 10, 981-984.

Matitaputty, J. K., Syamsuddin, H., Maryani, E., \& Ali, M. (2018). Contributions of Sasi to Sustainable Living of Saparua Indigenous Community, Indonesia. Proceedings of the 
Annual Civic Education Conference (ACEC 2018). Bandung, Indonesia: Universitas

Pendidikan Indonesia. https:// doi.org/10.2991/acec-18.2018.153

Matitaputty, J. K. (2019). Pagelaran Seni dan Budaya: Karakteristik Maluku sebagai Masyarakat

Multikultur dalam Mata Kuliah Pendidikan Multikultural. Jurnal Candrasangkala, 5(2), 113. Retrieved

from

https://jurnal.untirta.ac.id/index.php/Candrasangkala/article/view/6483

Matitaputty, J. K., \& Masinay, I. (2020). The Ceremonial Procession and Meaning of Makan Patita in Negeri Oma - Maluku. Society, 8(2), 298-312. https:// doi.org/10.33019/society.v8i2.181

Miles, M. B. (1992). Analisis Data Kualitatif: Buku Sumber tentang Metode-Metode Baru. Jakarta, Indonesia: UI- Press.

Muskitta, F. L. (2015). Kehidupan Musik Tahuri Masyarakat Negeri Hutumuri, Kecamatan Leitimur Selatan, Kotamadya Ambon Dalam Konteks Budaya. Ekspresi Seni: Jurnal Ilmu Pengetahuan dan Karya Seni, 17(1), 20-40. Retrieved from https://journal.isipadangpanjang.ac.id/index.php/Ekspresi/article/view/64

Nendissa, R. H. (2010). Eksistensi Lembaga Adat dalam Pelaksanaan Hukum Sasi Laut di Maluku Tengah. Jurnal Sasi, 16(4), 1-6.

Nurdiyanto, E., \& Yanti, S. N. H. (2019). Pengetahuan Ekologi Masyarakat Banyumas Mengenai Penamaan BUrung Merpati. Prosiding Seminar Nasional dan Call for Papers Pengembangan Sumber Daya Perdesaan Dan Kearifan Lokal Berkelanjutan IX. Purwokerto, Indonesia: Universitas Jenderal Soedirman.

Pasaribu, Y. A., \& Permana, R. C. E. (2017). Binatang-Binatang Totem Pada Seni Cadas $\begin{array}{lllll}\text { Prasejarah di Sulawesi Selatan. } & \text { AMERTA, }\end{array}$ https:// doi.org/10.24832/amt.v35i1.16

Riley, A. (2014). Flags, Totem Bodies, and the Meanings of 9/11: A Durkheimian Tour of a September 11th Ceremony at the Flight 93 Chapel. Canadian Journal of Sociology, 39(4). https://doi.org/10.29173/cjs19047

Salhuteru, M. (2015). Rumah Adat Baileo di Kecamatan Saparua Kabupaten Maluku Tengah. Kapata Arkeologi, 11(1), 11. https:/ / doi.org/10.24832/kapata.v11i1.278

Sopacoly, M. M., Lattu, I. Y. M., \& Timo, E. I. N. (2019). Sakralitas Waruga: Situs Suci dan $\begin{array}{lllll}\text { Identitas Kultural Masyarakat Minahasa. } & \text { FIKRAH, }\end{array}$ https://doi.org/10.21043/fikrah.v7i2.5055

Sugiyono. (2015). Metode Penelitian Kuantitatif, Kualitatif dan Kombinasi (Mixed Methods). Bandung, Indonesia: Alfabeta.

Suntoko, S., Pidentia, M., \& Ruhaliah. (2019). Sasi Role of Tradition in the Management and Conservation of Natural Resources as a Source of Human Life. Internasional Journal of Education and Research, 4(6), 333-340. Retrieved from https://www.ijern.com/journal/2016/June-2016/28.pdf

Touwe, M., Tuanaya, W., \& Wance, M. (2020). Sistem Pemilihan Raja Negeri Munarten Kecamatan Taniwel Kabupaten Seram Bagian Barat. Jurnal Studi Ilmu Pemerintahan, 1(2), 1-15. Retrieved from https://jurnal-umbuton.ac.id/index.php/jsip/article/view/688

Tunny, M. R., \& Tomia, D. (2018). Legitimasi Saniri Negeri: Studi Antropologi Budaya atas Resistensi terhadap Sistem Marga Kuasa di Negeri Seith. Dialektika, 8(1), 1-13. Retrieved from https://jurnal.iainambon.ac.id/index.php/DT/article/view/209

Ufie, A., Matitaputy, J. K., \& Kufla, J. (2020). Vean tradition as a local wisdom of customary people and its relevance to maritime history learning. Journal of Education and Learning (EduLearn), 14(4), 590-598. https://doi.org/10.11591/edulearn.v14i4.16401 
Vanessa, A., \& Anggraeni, L. K. (2020). Redesain Interior Fasilitas Pelayanan Administrasi Umum Universitas Kristen Indonesia (UKI) Berkonsep Modern Natural dengan Penerapan Nilai-Nilai Kristiani. Jurnal Sains dan Seni ITS, 9(2), 210-216. Retrieved from https://ejurnal.its.ac.id/index.php/sains_seni/article/view/56951

Widana, M., Arsana, I., \& Aliffiati. (2016). Rasionalitas Di Balik Perlakuan Masyarakat Terhadap Hewan Kerbau Di Desa Tenganan Pegringsingan, Kecamatan Manggis, Kabupaten Karangasem, Bali.. Humanis, 17(3), 137-145. Retrieved from https:/ / ojs.unud.ac.id/index.php/sastra/article/view/34616

Wonmut, X. (2017). Totemisme dan Perkawinan Sakramental. JUMPA (Jurnal Masalah Pastoral), 5(1), 53-72. $\quad$ Retrieved from https://ojs.stkyakobus.ac.id/index.php/JUMPA/article/view/37

Xiuping, H. H. M., Kissya, E., \& Yanes. (2010). Indigenous Knowledge and Customary Law in Natural Resource Management: Experiences in Yunnan, China and Haruku, Indonesia. Chiang Mai, Thailand: AIPP.

Zebua, F. E., Riyanti, \& Kurtini, T. (2016). Perbedaan Karakteristik Tubuh Merpati Tinggi Jantan dan Merpati Balap Jantan Lokal. Jurnal ILmiah Peternakan Terpadu, 4(3), 244-248. Retrieved from https://jurnal.fp.unila.ac.id/index.php/JIPT/article/view/1284

\section{About the Author}

Jenny Koce Matitaputty obtained her Doctoral degree in Social Science Education from Universitas Pendidikan Indonesia in 2018. The author is an Assistant Professor at the Department of History Education, Faculty of Teacher Training and Education, Universitas Pattimura, Indonesia.

E-Mail: jenny.matitaputty@fkip.unpatti.ac.id 